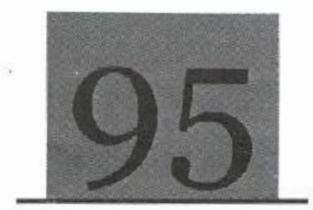

\title{
Comparative nutritional composition of smoked catfish (Clarias gariepinus) produced from NIOMR smoking kiln and local cut-drum oven
}

\author{
Okereke, A. N. I Opara, J. Y. I Opara, C.
}

\begin{abstract}
The effects of two different preservative equipment the NIOMR (Nigerian Institute for Oceunography and Marine Research) smoking kiln and local cut-drum oven - on crude protein, minerals and vitamins of C. gariepimus were studied. The fish were obtained from African Regional Aquaculture Centre, Alut, Port Harcourt. Moisture, crude protein, crude fibre, crude fat and ash content were determined using standard methods. There were significant differences $(P<0.05)$ in the moisture and crude fiber content. The moisture content of the fish sample ranged from 2.18 to 5.98 , this could be attributed to the drying methods. The crude fibre content ranged from 1.67 to 2.78 and shows no significant difference. The ash conient of the samples ranged from $0.25-0.6 \%$, an indication that smoking reduces the ash content of fish. Result of the crude protein of fresh fish was $21.84 \pm 1.10$ which increased to 59.5311 .88 and $35.41+1.00 \mathrm{in}$ both NIOMR smoking kiln and local oven respectively. This means that, there was a significant different in the effects of the two dryers on the crude protein. The vitamin content of both ovens showed no significant difference except in vitamin A which was significant in the fish dried with smoking kiln. There was significant different $(P<0,0.5)$ in the mineral conient of the two drying equipment, this was noiable in Sodium, Potassium and Phosphorus level of fish smoked with NIOMR smoking kiln. This result indicates that the iwo drying methods have varying effects on the nutritional quality of cat ish. which is in favour of NIOMR kiln.

Keywords: Smoking, production, preservative research, quality.
\end{abstract}

\section{Introduction}

$\mathrm{F}$ ish is a highly nutritious with high protein content. However, it is a suitable medium for growth of micro-organism. (Tull 1997) Smoked Fish being a foreign exchange earner for Nigeria, researchers are concerned about the quality of products, this was apparent from the investors forum that was jointly organized recently by NIOMR and the Raw Materials Rescarch and Development Council (RMRDC), where participants called for better handling, processing and packaging of products to meet the required standards set by authorities in the countries of export (Oyeleye, 2003). Thus, as dried fish continues to occupy its important place as a delicacy in the dishes of Nigerians. While drying of fish could extend its keeping quality thereby increasing the availability of fish all year round (Afolabi, et al., 1984). Fish smoking and drying naturally developed along the coastal fishing communities, the main objective being preservation of the catch for use over a long period of time (Adesula and Sydenham 2007). The traditional methods of processing are often inefficient and unhygienic involving substantial post harvest losses in terms of mould, fragmentation, infestation by flies and beetles, loss of quality by charring etc. the traditional or conventional methods can be improved and losses be reduced by the use of NIOMR smoking kiln and oven. It is instructive that the method has the effect of imparting a pleasant flavour to the product besides the preservative effect of the smoke itself (Burgress et al., 1965; Tull, 1997).

The most important factor affecting the quality of a fish product is the freshness of the raw fish immediately prior to processing. (Gokoglu et al., 2004) Poor quality raw fish produces poor quality end product. Processing can only help to slow down the rate of deterioration and using spoiled fish as the raw material ean only produce poor quality product (Tao and Linchan 2005). NIOMR Smoking kiln address the problems of traditional processing methods which predispose the artisanal catch to large scale post harvest losses estimated at over $20 \%$ of the total landed weight. Poor quality product due to fish being damaged by difficult handling of the fish on wire nets used to support them over the fire, loss of smoke and heat, resulting in uneven smoking, limited capacity of smoking larger volumes of fish, time consuming in terms of amount of time needed to handic the fish in smoking. 


\section{Materials and Methods}

Freshly harvested catfish (C. gariepinus) were obtained from the fish pond of African Regional Aquaculture Centre. The weight and length of the fish were $200 \pm 2.27 \mathrm{~g}$ and $20.67 \pm 0.98$ respectively. The fish samples were washed with tap water to remove dirt, rinsed with distilled water and were shared into three equal parts. The Proximate compositions of the fresh catfish were analyzed in the Laboratory. While the other two parts were dried using Nigerian Institute for Oceanography and Marine Research (NIOMR) smoking kiln and cut drum oven dried at temperature of $50^{\circ} \mathrm{C}$ for 4 hours and $50^{\circ} \mathrm{C}$ for 4 hours respectively and analyzed in the laboratory.

- Smoking process: The two other batches of fish were gutted and washed thoroughly with clean water and the first samples of fish placed inside the kiln at the temperature of $50^{\circ} \mathrm{C}$ for 4 hours and the other place in the oven at a temperature of $50^{\circ} \mathrm{C}$ for 4 hours. The smoke from the kiln and local oven was produced by the burning of charcoal. They were allowed to cool for 30 minutes flame from the smoking device and later, the two batches of fish for drying were homogenized using a kitchen blender kept in labeled airtight container and then analyzed in the central laboratory at National Institute of Root and Tubers Research, Umudike, Abia State, Nigeria.

- Determination of minerals: The minerals content of the samples was determined by the dry ash cxtraction method following the method described by Afolabi ct al. (1984) $2.0 \mathrm{~g}$ of the sample was burnt to ashes in a muffle (as in ash determination) the resulting ash was dissolved $100 \mathrm{ml}$ of dilute hydrochloric acid $(1 \mathrm{~m} \mathrm{HCl})$ and then diluted to $100 \mathrm{ml}$ in a volumetric flask using distilled water. The digest so obtained was used for the various analyses.

- Determination of potassium (k) and content: Two grams of the sample was weighed into small porcelain crucible and ashed in the furnace at $650^{\circ} \mathrm{C}$ for three hours. The ash was extracted by half filling the crucible with $2 \mathrm{ml}$ $\mathrm{IICl}$, boiled gently and the solution was transferred to a $50 \mathrm{ml}$ beaker using Pasteur pipette. The precipitates were washed with distilled water, filtered into the filtrate and solution made up to $50 \mathrm{ml}$ mark distilled water. K was determined using flame photometer (model: Jenway PFP 7) with standard solution while Fe was determined by Atomic Absorption spectrophotometer (AS) Bulk Scientific Model 210/211 VGP with standard solutions.

W- Weight of sample analyzed

Ew- equivalent weight

$\mathrm{V}_{\mathrm{F}}$ - Total volume of extract

$\mathrm{N}$ - Normally of EDTA $=0.02 \mathrm{~m}$

$\mathrm{V}_{\mathrm{A}}-\mathrm{Vul}$ of extract titrated

T- titre valve less black

- Determination of potassium and sodium: Potassium and sodium in the sample extract was determined by flame photometry the instrument was set up according to sample was calculated with reference to the graph and obtained as follows:

$$
\mathrm{Kmg} / 100 \mathrm{~g} \frac{100}{W}=\frac{V_{T}}{T} \times \frac{1}{10^{3}} \times \times \times D
$$

Where wt of sample used

$V_{\mathrm{T}}=$ total extract volume since $1 \mathrm{ml}$ was siphoned into the instrument.

Concentration from the graph

D- Dilution factor where applicable

- Determination of phosphorus: Phosphorus in the sample was determined by the vanadomohybdqate (yellow) spectrometry at a wave length of $420 \mathrm{~nm}$ described by Pearson. Phosphorus content was given by the formula:

$\mathrm{V}_{\mathrm{F}}$ - Total volume $\mathrm{g} / 100 \mathrm{~g}=100 / 10 \mathrm{X} \mathrm{Au} / \mathrm{AS} \mathrm{X} \mathrm{C} \mathrm{XV} \mathrm{V}_{\mathrm{A}}$ where of filtrate W-weight of sample analyzed

$\mathrm{V}_{\mathrm{A}}$ - Volume of $\mathrm{Au}$ - absorbance of standard of solution

- Statistical Analyses: Statistical analyses were performed using SPSSV. IS.O for windows. Analysis of variance (ANOVA) was used and statistical significance was set at $\mathrm{P}<0.05$. The least significant difference was used to separate differences in treatment means.

\section{Results}

Table 1: Mineral and crude protein levels of processed fish using different methods (Mean \pm SD).

\begin{tabular}{lccccccc}
\hline \multirow{2}{*}{ Fish sample } & \multicolumn{5}{c}{ Mineral levels (mg/100g) } \\
Fresh (control) & $209.46 \pm 1.1^{a}$ & $116.50 \pm 1.21^{a}$ & $187.78 \pm 1.01^{a}$ & $6.78 \pm 0.39$ & $221.64 \pm 1.01^{a}$ & $21.84 \pm 1.10^{\circ}$ & $131.51 \pm 1.009^{a}$ \\
Cut drum oven & $216.76^{b} \pm 10$ & $118.52 \pm 1.01^{b}$ & $194.24 \pm 1.12^{b}$ & $8.78 \pm 0.91^{c}$ & $224.78 \pm 2.01^{b}$ & $35.41 \pm 1.00$ & $134.71 \pm 2.12^{b}$ \\
Smoking kiln & $215.77^{b} \pm 1.01$ & $119.54 \pm 1.88^{b}$ & $192.88 \pm 2.14^{\circ}$ & $8.95 \pm 0.00^{\circ}$ & $237.98 \pm 4.87$ & $59.53 \pm 1.88^{\circ}$ & $137.56 \pm 4.54$ \\
\hline \multicolumn{7}{c}{ Means within the column with different superscripts are significantly different (p<0.05). }
\end{tabular}


Table 2: Vitamins levels in processed fish using different methods (Mean \pm SD).

\begin{tabular}{lcccccc}
\hline Fish sample & $\mathbf{B}_{1}(\%)$ & $\mathbf{B}_{2}(\%)$ & $\mathbf{B}_{3}(\%)$ & $\mathrm{E}(\mathrm{mg} / 100 \mathrm{~g})$ & $\mathrm{C}(\mathrm{mg} / 100 \mathrm{~g})$ & $\mathrm{A}(\mathrm{mg} / 100 \mathrm{~g})$ \\
Fresh & $0.08 \pm 0.01^{\mathrm{a}}$ & $0.06 \pm 0.01^{\mathrm{a}}$ & $1.11 \pm 0.10^{\mathrm{b}}$ & $0.45 \pm 0.01^{\mathrm{a}}$ & $0.86 \pm 0.01^{\mathrm{a}}$ & $15.42 \pm 0.10^{\mathrm{a}}$ \\
Cut drum oven & $0.05 \pm 0.01^{\mathrm{a}}$ & $0.04 \pm 0.01^{\mathrm{a}}$ & $0.96 \pm 0.01^{\mathrm{a}}$ & $0.39 \pm 0.10^{\mathrm{a}}$ & $0.62 \pm 0.01^{\mathrm{a}}$ & $11.28 \pm 0.20^{\mathrm{a}}$ \\
Smoking kin & $0.07 \pm 0.01$ & $0.05 \pm 0.01$ & $1.03 \pm 0.02$ & $0.42 \pm 0.02$ & $0.78 \pm 0.01$ & $13.89 \pm 0.88$ \\
\hline \multicolumn{7}{c}{ Means within the column with different superscripis are significantly different $(p<0.05)$}
\end{tabular}

Table 3: Proximate analysis of fresh and oven dried C. gariepinus.

\begin{tabular}{lllll}
\hline Fish sample & Moisture & Crude fibre & Crude fat & Ash \\
Fresh fish (control) & $78.70 \pm 2.78$ & $0.98 \pm 0.04$ & $0.58 \pm 0.05$ & $1.35 \pm 0.89$ \\
NIOMR kiln & $2.18 \pm 1.10$ & $2.18 \pm 1.10$ & $3.17 \pm 1.18$ & $1.18 \pm 1.10$ \\
Cut drum oven & $1.14 \pm 1.10$ & $1.14 \pm 1.07$ & $2.14 \pm 1.17$ & $2.25 \pm 1.10$ \\
\hline
\end{tabular}

\section{Discussion}

The crude protein content of fresh fish was $21.84 \pm 1.10$ and increased to $59.53 \pm 1.88$ and $35.41=1.00$ in both NIOMR smoking kiln and local oven respectively. This result agrees with the findings of Olayemi et al. (2011) who compared crude protein level of $C$. gariepinus dried with local cut drum oven and NSPRI developed smoking kiln. This means that, there was a significant different in both dryers on the crude protein. This will improve the knowledge and capacity of rural women and aquacultural communities on the appropriate processing methods for fish. The increase in protein level in NIOMR smoking kiln $(59.53 \pm 1.88)$ when compared with the oven dried catfish $(35.41 \pm 1.00)$ and fresh fish $(21.84+1.10)$ samples suggested that protein increases with NIOMR smoking kiln. The increase in protein contents may be due to product dehydration which concentrated the proteins during the heat treatment of the fish, thus increasing the nutritional value of the catfish.

The mineral in fresh, NIOMR smoking kiln and oven dried fish are shown in Table 1. Iron $8.78 \pm 0.91$ in oven dried and 7.96 \pm 0.00 in smoking kilri and calcium $224.78 \pm 2.01$ in oven dried and $228.3 \pm 1.01$ in smoking kiln are significantly different ( $(\mathrm{P}<0.05)$, while sodium, polassium and phosphorus levels are not significantly different in the two drying methods. The vitamin content in fresh, smoking kiln and cut drum oven dried are shown in Table 2 . There were no significant difference in the vitamin content except in vitamin A which was highly significant $(\mathrm{P}<0.05)$. This may be due to the effect of heat produced by smoking kiln has on the nutritional properties of $C$. gariepinus compared to the cut drum oven.

\section{Conclusion}

The results obtained in this study showed that the two drying methods had a great influence on the nutritional quality of fish. This study provided a possible application of NIOMR smoking kiln as an efficient drying process for fish. The design of the dryer ensured that the fish come out with a very low moisture content and long shelf life. It also gives good and efficient use of charcoal/firewood, which results in low fucl consumption, uniform fish drying, even temperature distribution, , produces dry fish that are hygienic that is free from grits cum heavy smoke deposits and highly adaptable to various scale of operation. In the case cut drum oven its use is limited to the poor resource fisher folks in the rural areas. This study cmphasizes the need of improved smoking kiln for drying. The knowledge obtained from this study will improve the capacity of rural women and fishing communities on appropriate drying method for fish. This study provides a possible application of NIOMR smoking kiln as an effective drying method.

\section{REFERENCES}

Adesuhu, E. and Sydenham, D. (2007). The Freshwater Fishes and Fisheries of Nigeria. Lagos: Macmillan. 397.

Afolabi, O., Arawomo, G. and Oke, O. (1984). Quality changes of Nigeria traditional processed freshwater species: Nutritive and organoleptic changes. Journal of food Technology, 19/333-340.

Burgess, G. H. O., Cutting, C. L., Lovern, J. A. and Waterman, J. J. (1965). Fish Handling and Processing. Tory Research Station, Ministry of Technology Edinburgh, Her Majesty's Station Office, London. 70-101.

Gokoglu, N., Verlikayup and Lengiz, E. (2004). Effects of cooking method on the proximate composition and mineral contents of Rainbow Trout (Oncorhynclus mykiss). Food Chemistry. 84:19-22.

Puroustein, P., Juriprasong, K., Kettwan, F., Va-sanaclih, K., Nak ngamanong, Y. and Bhattachiyee, L. (1999). Proximate composition of rwa and cooked that freshwater and marine fish. Joumal of Food Composition and Analysis, 12:416.

Oyeleye, O. (2003). Export potentials of smoked fish trade in Nigeria. The Guardian, Lagos.

Tao, W. and Linchan, O. N (2008). Influence of hot drying and microwave drying on nutritional and odorous properties of grass carp (Tenopharyngodon idellus) fillets. Journal of Fond Chemistry, 110: 647-653.

Tull, A. (1997). Food and Nutrition. 2nd Ed. Oxford University Press. 104-109. 